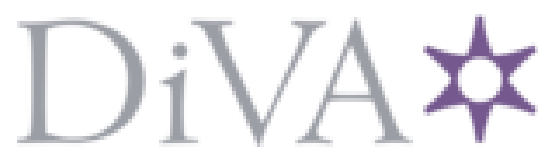

http://www.diva-portal.org

\title{
Postprint
}

This is the accepted version of a paper published in Nations and Nationalism. This paper has been peer-reviewed but does not include the final publisher proof-corrections or journal pagination.

Citation for the original published paper (version of record):

Tønnesson, S. (2016)

Will Nationalism Drive Conflict in Asia?.

Nations and Nationalism, 22(2): 232-242

http://dx.doi.org/DOI: 10.1111/nana.12184

Access to the published version may require subscription.

N.B. When citing this work, cite the original published paper.

Permanent link to this version:

http://urn.kb.se/resolve?urn=urn:nbn:se:uu:diva-294912 


\section{Will nationalism drive conflict in Asia?}

Manuscript version of article published in Nations and Nationalism 22(2): 232242.

\section{Stein Tønnesson}

In the Islamic world, the nationalist movements of the past are being superseded by trans-national Islamism, with its idea of reviving a trans-national Caliphate. Arab nationalism is in deep crisis. Interestingly, however, trans-national jihadism has not had much appeal in Muslim societies east of Pakistan and Afghanistan. Asia's Islamic political movements seem to have nationalist rather than trans-national Islamist agendas. So in East Asia, it is not trans-national Islamism but resilient or revived forms of local nationalism that drive conflicts. This includes anti-Muslim Buddhist nationalism in Myanmar as well as separatist movements among Muslim populations in the Philippines and Thailand.

Classic nationalism, aiming to merge statehood and ethnicity, remains very much a fact of life in East Asia. Over the last decade, both state nationalism and separatist ethnic nationalisms have been radicalized in some parts of the region while less assertive pluralist modes of national sentiment have taken hold in some of the most developed countries there. Is this ambiguous development likely to drive armed conflict in East Asia - a region that has enjoyed relative peace since the 1980s? When discussing this question, we shall look primarily at China, Taiwan and Japan as cases of state nationalism. For sub-state nationalism, Myanmar will serve as our main example.

The 70-year anniversary of the end of the Second World War in AugustSeptember 2015 provided an occasion for reviving and renewing nationalist ideologies in East Asia, through selective and conflicting memories. The events mirrored contemporary patterns of international alignment, with Russia reasserting its historical partnership with China against Japan, Taipei quarrelling 
with Beijing over which Chinese had won the war, South Korea repeating its call for Japanese apologies, and Japan expressing remorse for having challenged the international order in the 1930s and '40s in a way it fears that China may be about to do now.

There is a remarkable similarity between the narrative structures of Japan's Prime Minister Abe Shinzo's remorse speech on 15 August and Xi Jinping's celebration of China's victory in Beijing on 3 September 2015. Both leaders spoke about how their nation overcame a period of Western dominance in order to gain strength and prosperity. In Japan's case the rise had been derailed by militarism, and then rectified, so Japan could take its place as a normally armed nation:

"With their overwhelming supremacy in technology, waves of colonial rule surged toward Asia in the 19th century. There is no doubt that the resultant sense of crisis drove Japan forward to achieve modernization. Japan built a constitutional government earlier than any other nation in Asia. The country preserved its independence throughout. The Japan-Russia War [of 1904-05] gave encouragement to many people under colonial rule from Asia to Africa ... Japan took the wrong course and advanced along the road to war. And, seventy years ago, Japan was defeated ... In Japan, the post-war generations now exceed eighty per cent of its population. We must not let our children, grandchildren, and even further generations to come, who have nothing to do with that war, be predestined to apologize." (Abe 2015).

China's liberation from its hundred years of humiliation had been long and arduous, and has still not been completed:

"This great triumph [the 1945 victory] ... put an end to China's national humiliation of suffering successive defeats at the hands of foreign aggressors in modern times. This great triumph re-established China as a major country in the world and won the Chinese people [the] respect of all peace-loving people around the world. This great triumph opened up bright prospects for the great 
renewal of the Chinese nation and set our ancient country on a new journey after gaining rebirth." (Xi 2015).

Nationalist ideology, with its selective historical narratives, maintains its hold on most East Asian societies through education, museums and rituals. Is has had its ups and downs but there has been no good reason to assume that it would run its course, regardless of which theory of nationalism one subscribes to. If one believes that nationalist ideology can thrive only at a certain stage of socioeconomic development (Gellner 1983), and fades away when societies are integrated in a globalized economy and culture, then it is still too early for nationalism to fade away in East Asia. In spite of its prosperity, the Japanese culture has in no sense been globalized, and the Chinese, Indian and most other Asian societies remain at a stage of economic development where urbanization, growing middle classes and the spread of new information technologies stimulate national identity and fuel nationalist ideas.

If one believes instead that nationalism, defined as "an ideological movement for the attainment and maintenance of autonomy, unity and identity on behalf of a population deemed by some of its members to constitute an actual or potential 'nation'" (Smith 2000: 1), then it can play its role at any stage of socio-economic development since the emergence of the modern state system, and then the fact that nationalism retains its power in East Asia is even less surprising.

Fifteen years ago, the late Michael Leifer edited a volume for Routledge about Asian Nationalism, with chapters about China, Taiwan, Japan, India, Pakistan, and the Philippines, all written by scholars based at the London School of Economics. Anthony D. Smith wrote the introduction (2000: 18) and rounded it off with a prescient prediction:

"A world of competing nation-states, fuelled by uneven ethno-cultural resources and political power, is unlikely to wither away. Rather, the pressures of economic and political globalisation are ... likely to feed reactive cultural and political nationalisms through the 'demonstration effect' of successful 
movements and the dense communicative networks of ethno-cultural communities that feel liberated or threatened by new opportunities. In such an interdependent world of unsatisfied, but hopeful, ethnic nationalisms, the chances of transcending a world of nations must remain a dream of liberal cosmopolitans."

Nationalism will not have run its course as an ideological movement until the global state system has been fully and legitimately established on the basis of the national principle, or until another, transcending system has emerged. Even today this is unlikely to happen any time soon. The borders of the existing state system are fully accepted only in some parts of the world, mainly the Americas and West/Central Europe, and in both of these places there are controversies over the role of supranational institutions, over immigration from other regions, and over the status of some territories such as Scotland and Catalonia. In Asia there are many remaining border disputes, although quite a few have been resolved through bilateral agreements, sometimes also through third party adjudication. The disputes over the divided Korea, the status of Taiwan, over islands like the Kuriles/Northern Territories, Dokdo/Takeshima, Senkakus/Diaoyu, Scarborough Shoal, the Paracels, and the Spratlys, are used to fuel nationalist sentiments, in some cases by governments who need to enhance their domestic legitimacy and in other cases by opposition movements seeking to undermine the legitimacy of a government pursuing an accommodating foreign policy. Through official visits to disputed territories, and international initiatives to underpin national claims, mobilization of hate speech on the web, and organizing riots and demonstrations, governments hope to improve on their bargaining position vis-à-vis their international counterparts, while at the same time instilling fear among their opponents (Weiss 2014). National political leaders appeal to nationalist sentiments in order to mobilize popular support or shame their cautious domestic rivals.

Still today there are also many separatist movements whose nationalism aims to create a new smaller state on a part of a larger state's territory, unify a certain area with a part of a neighbouring state as part of an alleged ancestral homeland, 
or-if less radical-opt for autonomy within a more or less federal state. Such would-be new national states include among others Baluchistan, Kashmir, Assam, Nagaland, Kachin, Rakhine, Chin, Shan, Mon, Kayin, Wa, Aceh, West Papua, Bangsa Moro, Patani, Kampuchea Krom, East Turkestan, Tibet, and Inner Mongolia. Disputes over their status come in addition to the inter-state disputes over Korea, Taiwan, and the above-mentioned islands and maritime spaces.

With all of these unresolved and disputed sovereignty issues; there can be no surprise that nationalism maintains its grasp on Asia.

This calls for us to ask three questions:

1) How can we account for the variation in the intensity of nationalist sentiments among the various Asian societies?

2) How dangerous are the Asian nationalisms from the perspective of peace; will they drive open conflict?

3) What are the main mitigating factors?

First, for the variation, Myanmar may serve as example.

[Insert: Map of Myanmar]

It is perhaps the most complex and therefore most fascinating case in the world of a multi-national nation state, with a range of competing nationalisms, some accepting several layers of national identity, others rejecting Myanmar identity altogether because it is dominated by the ethnic Bamar (Burmans). The main ethnic groups in Myanmar have different nationalist agendas; different levels of enmity towards the country's longstanding military regime as well as the Bamar majority, and some have more radical goals than others. ${ }^{1}$ The Chin (in Chin State

1 The following is based on interviews made in Yangon, Myitkyina and Lashio during 2012-15, and on five reports from the Myanmar Peace Centre based on surveys of around 3,000 people in 
bordering Bangladesh and India) form a tight but poor largely Christian Baptist community whose territory is not much affected by immigration or the presence of other ethnic groups. They do not want independence since this would condemn them to poverty. Instead they want autonomy within the Union of Myanmar, and access to redistributed resources from more fortunate regions and states. The Kachin (in Kachin State and northern Shan State, bordering China) are also predominantly Christian (also mainly Baptist), strongly inspired from America and with a fierce will to fight against the Myanmar army (the hated Tatmadaw) but their state has vast resources, which have been plundered by local cronies and Chinese companies. The Kachin want their own independent state but could settle for autonomy if they are allowed to keep their own resources. The Kayin (Karen) are divided religiously between Christians and Buddhists, and are far more integrated with Bamar society than the Chin and the Kachin. After a continuous armed struggle since 1948 until it finally signed a ceasefire agreement in 2012, the Karen National Union is war weary. It has adapted its political goals to the fact that many Kayin have come to feel at ease in a Bamar-dominated society. Yet this remains controversial among the Kayin leaders. The Shan are yet more divided internally, and the huge Shan State comprises multiple ethnic groups. The Shan share the Buddhism of the Bamar majority, although with distinct variations. The Shan and Bamar tend to worship in separate temples. The Shan never had an independent kingdom historically, only a patchwork of principalities. Since 2011, the Mon and the Rakhine have profited from a radically increased freedom of speech and association to unleash a process of national awakening, reviving the memories of the periods when the Mon were free of Bamar domination and of the independent state of Arakan with its capital of Akyab (now Sittwe). In the last three years, Rakhine Buddhist nationalism has focussed much of its energy on opposing the presence on their territory of numerous Muslims with a historical background in Bengal. The local Muslims call themselves Rohingya and use that term in the names of their political organizations but the Rakhine (as well as most Bamar) refuse to recognize this name, and hence their existence as a separate cultural group. In a 
recent report from the semi-official Myanmar Peace Centre, the Rohingya are referred to only as "Non-Kaman Muslims" — the Kaman being a smaller, officially recognized minority group (Myanmar Peace Centre 2015: 3). Most Rakhine people see the Rohingya as illegitimate immigrants who should be denied any right of citizenship. In 2015 they were instructed to hand in their identity cards and although they had voted in the elections of 2010 they were not given voting rights in the regional and national elections of 8 November 2015. The Rakhine are not just anti-Muslim but also in opposition to the Bamar dominated Union government in Naypyidaw (Myanmar's capital since 2005) but as a coastal people they are keen to keep as much as possible of future revenues from offshore oil and gas, and from the port that shall serve as an entrepot for trade with western China through pipelines, roads and a railway. The Rakhine want autonomy and many harbour hopes for a fully independent Arakan. Yet this does not seem realistic even to the leaders of the Arakan National Party (ANP), one of the three winners of the November 2015 election, along with the Shan National League for Democracy (SNLD) and Aung San Suu Kyi's National League for Democracy (NLD). The southern part of Rakhine State is less independentminded, and the number of Rakhine living in Yangon is now almost at a par with the number in their own capital Sittwe. Although ethnic Bamar dominate Myanmar's former capital and largest city Yangon, all of Myanmar's ethnic minorities are represented among its population. A surprising feature of the November 2015 was the poor showing of the many ethnic parties, except for the ANP and SNLD. The NLD won majorities not only in the seven Bamar-dominated Regions but also in five of the seven ethnic States. The failure of most ethnic minority parties to win representation could strengthen the role of the ethnic armed groups and radicalize local ethnic nationalism.

In order to create a stable political system within its borders, the government of Myanmar has promised to engage in a national political dialogue with the aim to find compromises with all of the country's diverse sub-nationalisms. Aung San Suu Kyi says she is committed to such a dialogue. Any compromise emerging from the dialogue is likely to combine elements of federalism with various kinds of power sharing, and can probably not have the same form in each State or 
Region. To bring this dialogue to a conclusion will be hard, and there is considerable risk that armed conflicts will be ignited or re-ignited along the way. There could be much to learn from the Indian experience of diverse powersharing arrangements between New Delhi and the various Indian states, based on electoral alliances with dominant regional groups (Lacina 2014) and from the way the Indian Army has managed to avoid association with any particular ethnic group (Wilkinson 2015). Inspiration may also be sought from the Tunisian National Political Dialogue, who's driving Quartet was awarded the Nobel Peace Prize in 2015. When The Lady comes to power in 2016, in an uneasy constitutionally defined power sharing arrangement with the army, she will face the same kind of difficulties as have been faced in India and as General Thein Sein (President 2011-16) has been facing in the last four years. It would be unhelpful and divisive to emphasize the Buddhist character of the Bamar nation, as President $\mathrm{U} \mathrm{Nu}$ did in the last years of post-colonial Burmese democracy before the military seized power in 1962, and as groups of highly vocal monks (the "969" and "Ma Ba Tha" movements) were demanding in 2015. They supported the ruling Union Solidarity and Development Party (USDP), which is dominated by the military, as opposed to Aung San Suu Kyi's National League for Democracy (NLD), which was considered to be "soft on Muslims". Aung San Suu Kyi got a powerful popular mandate in the November 2015 elections. Yet tensions between the NLD and the Army, between radical Buddhist nationalists and secular reformers, and between multiple armed and unarmed ethnic groups, as well as the need to resolve the status of the Rohingya, will make it difficult for her to foster a sense of national unity.

Another example of how different national sentiments may overlap in the same country may be found in a comparison between Taiwan and China. While the Chinese Communist Party has taken over the nationalist ideology of the Taiwanbased Kuomintang Party, and now uses it as its second most important source of political legitimacy (after economic development), Taiwan's main political parties have played down both Chinese and Taiwanese nationalism because 
neither goes down well with the voters and the business community. Christopher Hughes pointed this out for Taiwan already in his chapter in the Asian Nationalism volume in 2000, and has followed it up later (Hughes 2006; 2011). He suggests that Taiwan has developed a post-nationalist situation because Chinese nationalism (an ideology in favour of one united China) has been tempered by the voters' lack of enthusiasm for national unification, while a separate Taiwanese nationalism has also been tempered by a similar reluctance to provoke hostile reactions from an increasingly powerful mainland China, which has become extremely important for Taiwan economically. Cautious realism among the voters and the business community has put brakes on nationalist impulses. On 3 September 2015, while Xi Jinping provided a unified all-Chinese version of the victory in "the Chinese People's Resistance War Against Japanese Aggression and the World Anti-Fascist War", President Ma Ying-yeou of the Republic of China in Taiwan emphasized the dominant role that Chiang Kai-shek's government and the Kuomintang Party had played at the time. Taiwan, however, also had room for highly dissonant voices: Kuomintang's former leader Lien Chan travelled to Beijing to be present at Xi Jinping's parade, while at the other extreme, Lee Deng Hui, also a former Kuomintang leader and president of Taiwan 1995-2000, went as far as to claim that the Taiwanese had been fighting on the side of Japan, not with China (Taiwan had been a part of the Japanese empire since 1895). Taiwan's political system has thus become sufficiently pluralistic to accommodate conflicting interpretations of history. This reduces the danger of excessive nationalism, and has a dampening effect internationally. President Ma's peace plans for the East China Sea and South China Sea, although barely noticed in the international press, have no doubt contributed to reducing tension in East Asia's territorial disputes. On 5 November 2015, Mr. Ma and Mr. Xi Jinping held a historical meeting in Singapore, reminding of the time in the 1920s, and again 1936-45, when the Kuomintang and Communist Parties formed a Soviet-supported united front against European and Japanese imperialism. The encounter in Singapore was hailed as a hugely important event in China, while it was widely criticized in the pluralist Taiwan. 
So far there is no similar pluralism in Mainland China, although the role of Chiang Kai-shek in resisting Japan is now recognized. The Chinese communist leaders have repeatedly allowed anti-Japanese nationalism to be played out both on the web and in the streets in conjunction with conflicts over prime ministerial visits to the Yasukuni Shrine, textbook controversies, attempts by Japan to obtain permanent membership in the UN Security Council, and disputes over the Senkaku/Diaoyu islands (Hughes 2006). The new nationalism in the Chinese media is based on a conception of history that bears close resemblance to the one that used to underpin the ideology of Chiang Kai-shek's Kuomintang, with emphasis on the history of national humiliation (Chiang 1947; Wang 2012). This now forms the historical basis for Xi Jinping's 'China Dream.' So the classic Kuomintang nationalist vision of a China that must be restored to greatness after a period of national humiliation has been taken over by the Chinese Communist Party. Meanwhile more pluralist ideas have taken hold in Taiwan, where scholars and politicians can discuss openly about history and people can mix elements of Taiwanese and Chinese identity — or choose between them.

Is nationalism dangerous? You bet! Just as politicized religion, nationalism is often geared towards motivating and legitimating the use of force by armies, militias and mobs. This is dangerous for Myanmar and dangerous for the world. In Myanmar a clash of nationalisms could derail the current attempt to open up, democratize and develop the economy. The country could then return to a situation of civil wars and military dictatorship.

The affirmation that nationalism is dangerous does not mean to deny the existence of moderate and peaceful forms of nationalism. Allen Whiting's distinction between affirmative, assertive and aggressive nationalism continues to make sense (Whiting 1995). If nationalists aim mainly to generate a participatory all-inclusive we-feeling among the citizens of a state that has no big quarrels with its neighbours, then we have a case of benevolent affirmative nationalism. 
The dangerous nature of assertive, and notably aggressive nationalism can be illustrated through a very big example:

Three different kinds of nationalism characterise the China-Japan-US power triangle. Current developments within the triangle represent an even more dangerous threat to world peace than the crisis in the Russia-EU-US triangle after the 2014 Russian annexation of the Crimea and subsequent interventions in eastern Ukraine and Syria. It also counts here that China and Russia have developed a tight strategic partnership and that Vladimir Putin is the most admired foreign leader in China, at least in official circles. When he presided over the Russian military parade in Moscow on 9 May 2015, on the occasion of the Great National Victory over Nazi Germany, the only prominent leader to stand by his side was Xi Jinping. When Xi presided over the parade in Beijing on 3 September 2015, the only prominent foreign leaders to stand by his side were Putin and South Korean president Park Geun-hye.

Japan is the main villain in the Chinese story of national humiliation. It defeated China in 1895, seizing Taiwan, and annexed Korea in 1910. It established itself on the Chinese coast in the First World War, provoking the 4th May antiJapanese movement. It conquered Manchuria in 1931, and invaded China in 1937, committing numerous atrocities. These events were duly commemorated in China in August-September 2015, but Xi Jinping's speech at the military parade was not bellicose. He reiterated China's dedication to "peaceful development". In Whiting's words, China's current nationalism is assertive but not aggressive.

On its side, Japan's conservative nationalists, who have always aimed to revise Article 9 in its constitution so Japan could become a "normal nation", scored a victory when Abe Shinzo's new interpretation of Article 9 was adopted in the form of a law in September 2015. In clear contradiction of the words and intention of Article 9, Japan can now take part in "collective defence." This means it can fight alongside US forces when they intervene abroad. Japanese 
nationalism differs from China's in important ways. Japan's is not youthful, nor is it playing itself out in the streets. The Japanese population seems neither enthusiastic about nor hostile to the nationalist agenda of refusing to make new apologies for past war crimes, restoring Japan as a "normal nation," standing up against China's assertiveness, and reducing in the long term its dependence on US protection. Nationalist politicians like Prime Minister Abe are neither punished nor credited for their nationalism at the polls. What counts most for Japan's voters is the economy. This would likely have been the same in China if it had competitive elections. Japan, just like Taiwan, is a plural society where activists defending Article 9 manifest themselves freely in opposition to the government. Japanese nationalism is contested openly in a free society in a way that is so far impossible in China.

American nationalism is also important in the context of Asia. In the USA there is a strong reservoir of resentment and suspicion against China, which could lead to the adoption of protectionist measures or demonstrations of military might or both. Such measures would probably be acclaimed by much of public opinion if adopted by a reckless president. China has so far mostly eluded American nationalist hostility because of its economic importance and because Middle Eastern terrorists and other troublemakers keep the hands of the US military and diplomats full. Yet it seems likely that there will be new incidents between the two mutually suspicious great powers, which could lead to strong manifestations of nationalist sentiments on both sides of the Pacific.

What are the main mitigating factors? How can the aggressive nationalist impulse be contained?

Supra-national institutions may have a dampening effect on nationalist behaviour: In spite of its institutional weakness, ASEAN has played a role in reducing inter-state tension in Southeast Asia. It was formed in 1967 as a means to end Confrontation between Indonesia and Malaysia, avoid conflict between 
the Philippines and Indonesia, and include Singapore in a regional grouping. ASEAN's original member states have not fought each other since the organization was born. Indonesia and Malaysia, and Malaysia and Singapore have resorted to international arbitration to resolve territorial disputes, and ASEAN has created frameworks for security talks in a wider region (ASEAN+3; ASEAN Regional Forum, East Asian Summit). Yet ASEAN remains a weak organization with a Secretary General who can only act when all member states agree. Thus ASEAN could not prevent clashes between Thailand and its new member Cambodia in 2009-11.

According to Hechter (2000: 134) two factors serving to contain nationalism are "conditions ... that lower the salience of national identity, and those that decrease the demands for national sovereignty." It has already been mentioned how a realist and risk-aware electorate put brakes on the nationalist agenda in Taiwan. Interestingly, the yellow shirts in Thailand also failed to mobilize nationalist opinion behind their campaign against Cambodia over the issue of the disputed area around the temple Preah Vihear. The salience of national identity in Thailand thus did not seem as great as some had thought. The victory won by Aung San Suu Kyi's NLD in Myanmar's 8 November 2015 national elections also indicates that the Buddhist nationalist campaign in favour of the ruling militarydominated USDP overestimated the appeal of xenophobia. It is also far from evident that the sovereignty disputes in the East China and South China Seas are matters that could stir up nationalist sentiments among a wider population.

It is primarily when occurring in conjunction with people's deeply felt concerns for their livelihood that nationalism takes on dangerous proportions. Thus the key to containing nationalism may be national priority for economic development. That East Asia has been so peaceful since the 1980s is mainly because all its leading nations have prioritized economic growth through integration in the global market (Tønnesson 2015).

So one piece of consolation in the current situation is that the main future goal declared by Xi Jinping under his 'China Dream' is to make China into a 
moderately prosperous nation by 2021 and a "fully developed nation" by 2049 . To make this realistic China will need stable international relations as well as stability internally. Xi Jinping links his development goals to regime survival by choosing the years 2021 and 2049, the centennials of the foundation of the Chinese Communist Party and the founding of the People's Republic of China. He does not intend to introduce much freedom or democracy. But he may be likely to stick to the aim of "peaceful development," keep nationalist sentiments under control, and avoid open confrontation with Japan and the USA.

Nationalism will continue to have its ups and downs. It will cause much worry and some suffering but as long as nations are concerned for their economic wellbeing and do not resort to protectionist impulses, nationalism is unlikely to drive war.

\section{References}

Abe Shinzo (2015) 'Statement by Prime Minister Shinzo Abe' 14 August: http://japan.kantei.go.jp/97_abe/statement/201508/0814statement.html Ash, Robert, John W. Garver and Penelope B. Prime, eds (2011) Taiwan's Democracy: Economic and political challenges. London: Routledge.

Center for Diversity and National Harmony (2015) Rakhine State Needs Assessment. Yangon (September).

Chiang Kai-shek (1947) China's Destiny. New York: Macmillan.

Gellner, Ernest. (1983)Nations and Nationalism. Oxford: Blackwell.

Hechter, Michael (2000) Containing Nationalism. Oxford: Oxford University Press.

Hughes, Christopher (2000) 'Post-nationalist Taiwan.' In Leifer: 63-81.

Hughes, Christopher R (2006) Chinese Nationalism in the Global Era. London: Routledge.

Hughes, Christopher R (2011) 'Negotiating national identity in Taiwan: between nativization and de-sinicization.' In Ash et al: 51-74.

Lacina, Bethany (2014) 'Ethnicity, Territory, and Conflict under Indian Federalism: A Book Proposal':

http://www.bethanylacina.com/Lacina_prospectus.pdf 
Leifer, Michael (2000), ed. Asian Nationalism. London: Routledge.

Myanmar Peace Centre (2015) Citizen Voices in Myanmar's Transition: Kachin State; Mon State; Kayin State; Rakhine State; Northern Shan State. Yangon (5 vols).

Smith, Anthony D (2000) 'Theories of nationalism: alternative models of nation formation.' In Leifer 2000: 1-20.

Tønnesson, Stein (2015) 'East Asia’s Developmental Peace.' Global Asia 10(4): Winter.

Wang Zheng (2012) Never Forget National Humiliation: Historical Memory in Chinese Politics and Foreign Relations. NY: Columbia University Press.

Weiss, Jessica Chen (2014) Powerful Patriots: Nationalist Protest in China's Foreign Relations. Oxford: Oxford University Press.

Whiting, Allen S. (1995) 'Chinese Nationalism and Foreign Policy after Deng.' The China Quarterly142 (June): 295-316.

Wilkinson, Steven (2015) Army and Nation: The Military and Indian Democracy since Independence. New Haven: Harvard University Press.

Xi Jinping (2015) 'Address at the Commemoration of The 70th Anniversary of The Victory of the Chinese People's War of Resistance Against Japanese Aggression and The World Anti-Fascist War' 3 September: http://news.xinhuanet.com/english/2015-09/03/c_134583870.htm 